В основу положена классификация угодий по типам интенсивности антропогенного воздействия на территорию, где земельные угодья ранжируются следующим образом: 1) застроенные, 2) возделываемые, 3) используемые в естественном виде, 4) неиспользуемые земли. К застроенным относятся земли промышленности, поселений, транспорта; к возделываемым - пашня, к используемым в естественном виде - пастбища, сенокосы, водные объекты, к неиспользуемым болота, лесные земли и др. [10].

Для определения уровня антропогенной преобразованности предлагается коэффициент относительной напряженности экологохозяйственного состояния территории $\left(\mathrm{K}_{0}\right)$. Этот показатель охватывает всю изучаемую площадь и дает наиболее полные представления о сложившейся ситуации (района) региона. $\mathrm{K}_{0}$ представляет собой отношение площади земель с высокой антропогенной преобразованностью к площади с низкой антропогенной преобразованностью. Чем выше значение коэффициента $\mathrm{K}_{0}$, тем напряженнее ситуация. При $\mathrm{K}_{0}$, близком к 1,0 , достигается соотношение угодий, при котором эколого-хозяйственная система является сбалансированной и устойчивой.

Таким образом, главное содержание эколого-хозяйственного баланса - совершенствование структуры землепользования и создание новых структур землепользования на основе соответствия структурных элементов ландшафта и видов использования земель, а также ориентация на постоянное расширение природных систем жизнеобеспечения человека. Особую значимость имеет повышение устойчивости геосистем за счет более эффективной их управляемости.

УДК: 910.3

\section{ДОСТУПНОСТЬ ПРОДОВОЛЬСТВИЯ В РЕГИОНАХ ПРИВОЛЖСКОГО ФЕДЕРАЛЬНОГО ОКРУГА}

\section{И.А. Ильченко}

Саратовский государственный университет, кафедра экономической географии E-mail: IRA-ILCHENKO@YANDEX.RU

В данной статье автором определено место Саратовской области среди регионов Приволжского округа по доступности продуктов питания, исходя из материальных возможностей населения; предложены показатели, характеризующие уровень благосостояния населения; проведена классификация регионов ПФО по данным характеристикам; охарактеризована динамика покупательных возможностей населения.

Ключевые слова: потребление продовольствия, денежные доходы населения, прожиточный минимум, стоимость продовольственной корзины, структура потребительских расходов.

\section{Библиографический список}

1. Кушнарёв А.И. Повышение эффективности лесомелиоративных мероприятий на пастбищах Саратовского Заволжья: Автореф. дис. ... канд. с.-х. наук. Саратов, 2006. $20 \mathrm{c}$.

2. Петриков А.В., Галас М.Л. Сельское хозяйство России в XX веке // Россия в окружающем мире - 2001: Аналитический ежегодник / Отв. ред. Н.Н. Марфенин. М., 2001. C. 52-79.

3. Васильчук Н.С., Шабаев А.И., Курдюков Ю.Ф., Михайлин Н.В. Освоение и использование целинных и залежных земель в засушливых условиях Поволжья // Повышение эффективности использования агробиоклиматического потенциала юго-восточной зоны России / ГНУ НИИСХ ЮгоВостока Россельхозакадемии. Саратов, 2005. С. 43-47.

4. Булгаков Д.С., Карманов И.И. Влияние земледелия на экосистемы // Земледелие на рубеже XXI века: Сб. докл. Междунар. науч. конф. М., 2003. С. 164-172.

5. Дёжкин В.В., Попова Л.В. Основы биологического природопользования: Учеб. пособие. М., 2005. 320 с.

6. Измаильский А.А. Как высохла наша степь. М.; Л., 1937.

7. Докучаев B.B. Наши степи прежде и теперь. М.; Л., 1936.

8. Николаев В.А., Пичугина Н.В. Агроэкологические уроки векового опыта земледелия в Прикаспийской глинистой полупустыне // География и региональная политика: Материалы междунар. науч. конф. Смоленск; СПб.; М., 1997. Ч. 2. С. 116-119.

9. Кочуров Б.И. Геоэкология: экодиагностика и экологохозяйственный баланс территории. Смоленск, 1999. C. 3-7.

10. Кочуров Б.И., Иванов Ю.Г. Оценка экологохозяйственного состояния территории административного района // География и природные ресурсы. 1987. № 4. С. $49-54$.

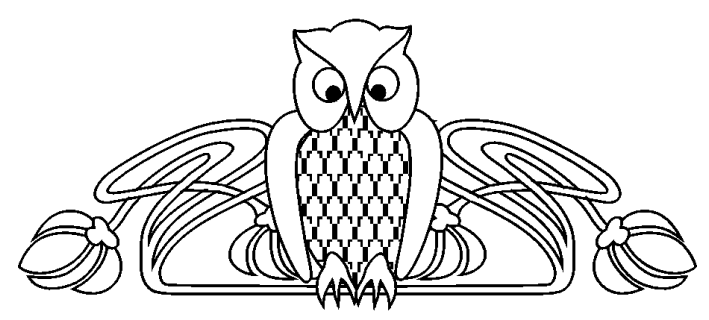

Possibility of Buing of Food-Stuffs in Regions of Privolzskiy Federal Areal

\section{I.A. Ilchenko}

Possibility of buing of food-stuffs in Regions of Privolzskiy Federal Areal. The position of Saratov region among the other areas of Privolshsky region concerning the food consumption is shown in the article. This position is the most important index of food safety level. In the article the salary is represented as en element buing of food-stuffs and buyer ability.

Key words: buing of food-stuffs, food consumption, food safety, buyer ability. 
Процессы рыночного реформирования экономики привели к негативным изменениям уровня и структуры потребления жизненных благ населением. Особенно тревожит тот факт, что это касается потребления продуктов питания. Как показывают данные статистики, даже в регионахлидерах экономического развития Российской Федерации душевые уровни потребления продовольствия достигают физиологических норм далеко не по всем основным продуктам. В остальных регионах разрыв между нормами и фактическим потреблением еще больше.

Регионы Приволжского федерального округа (ПФО) располагают благоприятными агроклиматическими условиями для производства продовольствия. Часть из них входит в число крупнейших производителей сельскохозяйственной продукции в стране: республики Татарстан и Башкортостан, а также Саратовская область. Однако на уровень потребления продовольствия оказывает влияние не только физическая (наличие продуктов питания на потребительском рынке), но и экономическая доступность продовольствия (материальные возможности населения по приобретению продовольствия).

Цель работы заключается в определении места Саратовской области среди регионов Приволжского округа по доступности продуктов питания исходя из материальных возможностей населения. Задачами исследования являются выявление показателей, которые характеризуют возможности населения по приобретению продовольствия; проведение классификации регионов ПФО исходя из возможностей покупки продуктов питания; характеристика динамики покупательных возможностей населения Саратовской области. Теоретической основой данной работы являются исследования экономистов Самарской государственной экономической академии в области потребления продовольствия на региональном уровне $[1,2]$.

Непосредственной основой материального обеспечения уровня жизни являются доходы населения. Критериями доступности продовольственных товаров выступают среднедушевой денежный доход, соотношение денежных доходов и прожиточного минимума, денежных доходов и стоимости продовольственной корзины, структура потребительских расходов и удельный вес расходов на питание.

Доходы населения являются одним из наиболее обобщающих показателей роста благосостояния людей. Регионы Приволжского округа в зависимости от величины денежных доходов населения можно разделить на четыре группы. В первую группу, в которой денежные доходы населения превышают средние доходы по округу, входят республики Башкортостан и Татарстан, Пермский край и Самарская область (табл. 1) [3]. Ко второй группе, где денежные доходы равны средним по округу, относится Нижегородская область. Третья группа включает регионы с доходами ниже средних: Удмуртия и Кировская, Оренбургская, Пензенская, Саратовская и Ульяновская области. Четверная группа - это регионы, где денежные доходы значительно ниже средних по округу: республики Мордовия, Чувашская и Марий Эл. Таким образом, в большей части регионов Приволжского федерального округа, в том числе и в Саратовской области, денежные доходы ниже средних по округу (см. табл. 1).

Таблица 1

Денежные доходы населения в регионах Приволжского федерального округа (2006 г.)

\begin{tabular}{|l|c|c|c|c|}
\hline \multirow{2}{*}{ Регионы } & \multirow{2}{*}{\begin{tabular}{c} 
Место ре- \\
\cline { 3 - 5 }
\end{tabular}} & & \multicolumn{3}{|c|}{ Денежные доходы } \\
\cline { 3 - 5 } & & $\begin{array}{c}\text { Соотношение } \\
\text { г ПФО, ра3 }\end{array}$ & $\begin{array}{c}\text { Соотношение } \\
\text { с РФ, ра3 }\end{array}$ \\
\hline Российская Федерация & - & 10183 & - & - \\
\hline Приволжский федеральный округ & - & 7989 & - & 0,78 \\
\hline Республика Башкортостан & 4 & 8909 & 0,62 & 0,87 \\
\hline Республика Марий Эл & 13 & 4909 & 0,61 & 0,48 \\
\hline Республика Мордовия & 14 & 4879 & 1,17 & 0,48 \\
\hline Республика Татарстан & 3 & 9369 & 0,78 & 0,61 \\
\hline Республика Удмуртская & 6 & 6228 & 0,67 & 0,53 \\
\hline Республика Чувашская & 12 & 5384 & 0,72 & 0,57 \\
\hline Кировская область & 10 & 5773 & 0,99 & 0,79 \\
\hline Нижегородская область & 5 & 8016 & 0,77 & 0,61 \\
\hline Оренбургская область & 7 & 6175 & 0,71 & 0,56 \\
\hline Пензенская область & 11 & 5659 & 1,37 & 1,08 \\
\hline Пермский край & 2 & 10982 & 1,44 & 1,13 \\
\hline Самарская область & 1 & 11529 & 0,76 & 0,60 \\
\hline Саратовская область & 9 & 6135 & 0,77 & 0,61 \\
\hline Ульяновская область & 8 & 6157 & & \\
\hline
\end{tabular}

Примечание. Рассчитано автором по: www.gks.ru 
Если сопоставить денежные доходы регионов округа со среднероссийскими, то еще в меньшем количестве регионов этот показатель будет выше среднего: Самарской области и Пермском крае. В оставшихся двенадцати регионах среднедушевые денежные доходы в 2006 году были существенно ниже среднероссийских. Саратовская область принадлежит к числу регионов с существенной (на треть) разницей между собственными и среднероссийскими доходами.

Уровень потребления продуктов питания напрямую зависит от соотношения величин среднедушевых денежных доходов и прожиточного ми- нимума. Это соотношение отражает возможность населения пробрести определенный объем товаров и является одним из важнейших показателей уровня жизни. Соотношение денежных доходов населения с величиной прожиточного минимума выше, чем в среднем по Приволжскому федеральному округу, в четырех регионах - в Самарской и Пермской областях, в республиках Башкортостан и Татарстан, в остальных регионах - в республиках Мордовия, Марий Эл, Удмуртской и Чувашской, Кировской, Нижегородской, Оренбургской, Пензенской, Ульяновской и Саратовской областях - это соотношение ниже среднего по округу (табл. 2) [3].

Таблича 2 Соотношение денежных доходов с величиной прожиточного минимума и стоимостью минимального набора продуктов питания в регионах Приволжского федерального округа (2006 г.)

\begin{tabular}{|l|c|c|c|c|}
\hline \multicolumn{1}{|c|}{ Регионы ПФО } & $\begin{array}{c}\text { Величина прожи- } \\
\text { точного минимума } \\
\text { (в среднем на душу } \\
\text { населения), руб. в } \\
\text { месяц }\end{array}$ & $\begin{array}{c}\text { Соотношение } \\
\text { сенежных доходов } \\
\text { житочного мини- } \\
\text { мума, \% }\end{array}$ & $\begin{array}{c}\text { Стоимость ми- } \\
\text { нимального на- } \\
\text { бора продуктов } \\
\text { питания, руб. }\end{array}$ & $\begin{array}{c}\text { Соотошение денеж- } \\
\text { мости минимального } \\
\text { набора продуктов } \\
\text { питания, \% }\end{array}$ \\
\hline Российская Федерация & 3437 & 296 & 1474 & 690 \\
\hline Приволжский федеральный округ & 3009 & 265 & 1310 & 609 \\
\hline Республика Башкортостан & 2973 & 299 & 1306 & 682 \\
\hline Республика Марий Эл & 2789 & 176 & 1255 & 391 \\
\hline Республика Мордовия & 2816 & 173 & 1255 & 388 \\
\hline Республика Татарстан & 2695 & 347 & 1197 & 782 \\
\hline Республика Удмуртская & 2947 & 211 & 1254 & 496 \\
\hline Республика Чувашская & 2712 & 198 & 1190 & 452 \\
\hline Пермский край & 3571 & 307 & 1347 & 815 \\
\hline Кировская область & 3066 & 188 & 1376 & 419 \\
\hline Нижегородская область & 3255 & 246 & 1361 & 588 \\
\hline Оренбургская область & 2734 & 225 & 1275 & 484 \\
\hline Пензенская область & 2999 & 188 & 1310 & 431 \\
\hline Самарская область & 3727 & 309 & 1482 & 777 \\
\hline Саратовская область & 2919 & 210 & 1311 & 467 \\
\hline Ульяновская область & 2936 & 209 & 1256 & \\
\hline
\end{tabular}

Примечание. Рассчитано автором по: www.gks.ru

Денежные доходы не могут обеспечить высокий уровень потребления, если цены на продукты в регионе высокие. Поэтому целесообразно рассмотреть соотношение денежных доходов и стоимости минимального набора продуктов питания, включающего 25 основных продуктов. Чем больше превышение денежных доходов над стоимостью продовольствия, тем больший объём продуктов может позволить себе население. В Пермском крае, Татарстане и Самарской области превышение денежных доходов над стоимостью минимального набора продуктов питания максимально. Саратовская область по соотношению денежных доходов и стоимости минимального набора продуктов питания занимает в рейтинге 8-е место. Соотношение денежных доходов и стоимости набора продуктов питания в Саратовской области ниже, чем в среднем в Приволжском округе, так же как и в Оренбургской, Пензенской, Ульяновской, Нижегородской, Кировской областях, в республиках Мордовия, Марий Эл, Чувашская и Удмуртская.

Учитывая то, что потребительские цены растут быстрее, чем доходы населения, целесообразно рассмотреть изменение покупательной способности населения в отношении продовольствия (табл. 3) [4]. 
Таблица 3

Покупательная способность денежных доходов населения Саратовской области по товарным группам продовольствия

\begin{tabular}{|l|c|c|c|c|c|}
\hline $\begin{array}{c}\text { Возможность покупки продук- } \\
\text { тов питания (в месяц) }\end{array}$ & 1996 & 1999 & 2000 & 2004 & 2006 \\
\hline Хлебопродукты, кг & 1710 & 198 & 293 & 280 & 350 \\
\hline Молоко, кг & 1221 & 226 & 303 & 293 & 412 \\
\hline Яйца, шт & 2265 & 1201 & 2350 & 1520 & 3097 \\
\hline Говядина, кг & 137 & 43 & 71 & 53 & 52 \\
\hline Рыба, кг & 610 & 90 & 120 & 113 & 116 \\
\hline Картофель, кг & 427 & 399 & 680 & 648 & 519 \\
\hline Овощи, кг & 380 & 360 & 657 & 591 & 622 \\
\hline
\end{tabular}

Примечание. Сост. по: Саратовская область в цифрах. 2006: Стат.сб. / Территориальный орган Федеральной службы государственной статистики по Саратовской области. Саратов, 2007.

Наиболее резкое снижение покупательной способности произошло в период 1996-1999 гг., что вызвано ростом цен на фоне уменьшения денежных доходов населения. В период 19992006 гг. наблюдается увеличение покупательной способности, так как с 1999 г. не происходило опережающего повышения цен и доходы росли с небольшим интервалом на уровне цен.

Ещё один показатель уровня жизни населения - доля населения с доходами ниже прожиточного минимума. В период 2000-2006 гг. в Саратовской области доля населения с доходами ниже прожиточного минимума снизилась с 44,2 до $22,0 \%$ (в России она составляет сейчас 15\%). Среди субъектов Приволжского федерального округа область находится на среднем уровне. Намного меньшую долю населения с доходами ниже прожиточного минимума имеют республики Татарстан, Башкортостан, Пермский край, Нижегородская и Самарская области.

Ситуацию усугубляет дальнейшее расслоение населения по уровню денежного дохода и, соответственно уровню потребления. Дифференциация доходов является одним из объективных и закономерных явлений рыночной экономики. В 2006 г. среднедушевые денежные доходы наиболее обеспеченной группы населения превысили доходы наименее обеспеченной в 17,5 раза, тогда как в 1996 г. - в 11,9 раза [3]. Наблюдалась довольно высокая степень различия в денежных доходах населения с тенденцией к ее усилению.

Показателем благосостояния людей в большинстве стран мира считают долю расходов на питание в бюджете семей. Высокая доля расходов на питание характерна для бедных слоев населения. Доля продовольственных товаров в структуре расходов была достаточно высока в 2000 г. - 49,6\% у городского и 44,1\% у сельского населения, но к 2006 г. она снизилась до 45,1\% и до 36,9\% соответственно. Заметно повысилась доля расходов на непродовольственные товары у городского населения, при этом у сельского она осталась на прежнем уровне, и двукратно повысилась доля расходов на культурно-бытовые услуги в обеих группах. Однако в целом можно говорить о низких денежных доходах населения, так как основная их часть идет на покупку продовольствия. В то же время существует небольшая положительная тенденция к снижению доли расходов на продовольствие, благодаря которой структура расходов будет меняться в сторону товаров и услуг так называемой «высшей категории».

Итак, Саратовская область характеризуется низким уровнем денежных доходов как среди субъектов Приволжского федерального округа, так и среди российских регионов; то же касается и соотношения доходов и величины прожиточного минимума. Саратовская область по соотношению денежных доходов и стоимости минимального набора продуктов питания находится на средних позициях в округе. За исследуемый период покупательная способность в отношении таких важных белоксодержащих продуктов, как мясные и молочные, снизилась в 3 раза, хлеба и хлебопродуктов - в 6 раз и только на картофель и овощи возросла. В целом уровень денежных доходов населения Саратовской области, по сравнению с другими регионами ПФО, оценивается ниже среднего, а динамика покупательной способности является отрицательной.

\section{Библиографический список}

1. Баканач О.Б., Зарова Е.В. Нестабильность сельскохозяйственного производства как фактор угрозы продовольственной безопасности в регионе // Вопр. статистики. 2002. № 2. C. 24-26.

2. Баканач О.Б., Зарова Е.А. Продовольственная безопасность Самарской области: методология исследования и прогнозирования. Самара, 2002.

3. Регионы России. Т. 14. Сельское и лесное хозяйство: Стат. сб. М., 2007. 430 c.

4. Колесняк A.A. О региональной продовольственной безопасности // Междунар. сельскохоз. журн., М., 2005. № 1. С. 62 . 